\title{
TYPE II DIABETIC PATIENTS; USE OF CAMEL MILK IN KARACHI: A CROSS SECTIONAL SURVEY
}

1. MBBS, MPH

Assistant Professor,

Department of Community Health

Sciences, Jinnah Medical \& Dental College, Karachi

2. MBBS, MSc.

Assistant Professor,

Department of Community Health

Sciences, Jinnah Medical \& Dental College, Karachi.

3. MBBS, FCPS

Assistant Professor

Department of Medicine,

Jinnah Medical College Hospital,

Karachi.

Correspondence Address:

Dr. Zeba Saeed

Assistant Professor

Department of Community Medicine

Jinnah Medical \& Dental College

22-23, Shaheed-e-Millat Road

Karachi 74800

zebasaeed437@gmail.com

Article received on:

20/05/2015

Accepted for publication:

06/07/2015

Received after proof reading:

09/09/2015

\section{Dr. Zeba Saeed ${ }^{1}$, Dr. Zainab Hasan², Dr. Fadieleh Adnan Sohail ${ }^{3}$}

ABSTRACT... Objectives: To determine the frequency of camel milk users as a dietary adjunct therapy in Diabetes Type 2. Study Design. A cross sectional questionnaire based survey. Period: May to August 2013. Setting: Liaquat National Hospital \& Jinnah Medical College Hospital) and one public sector hospital (Jinnah Postgraduate Medical Centre) in Karachi. Methods: Minimum sample size using $11.1 \%$ prevalence of type II diabetes mellitus, confidence interval of $95 \%$ and $5 \%$ margin of error and finite population correction for large population was calculated to be 152. Using purposive sampling, type II diabetes patients (taking oral hypoglycemic medication or insulin to control serum blood glucose) visiting outpatient departments for diabetes management at two private and one public sector hospital in Karachi, were requested to participate. After obtaining informed consent, a structured pre-coded questionnaire was filled by trained interviewer. Two laboratory assessed fasting blood (FBG) readings from previous three months were also recorded from their files. Those who affirmed the use of camel milk were asked further questions on reasons and consumption pattern. All responses were entered into SPSS version 17.0 and descriptive frequencies and statistics were obtained for camel milk users and non-users. Results: 300 patients consented to participate and filled the questionnaire. 36 forms did not have two FBG lab reports from previous three months and were excluded. In the remaining sample size of $n=264$, camel milk use frequency was $35.98 \%(n=95)$. In the preceding three months, the median FBG of users was $121.0 \mathrm{mg} / \mathrm{dl}$ as compared to median FBS of non-users $(64.01 \% ; n=169)$ of $202.06 \mathrm{mg} / \mathrm{dl}$. $90.5 \%(n=86)$ of all users considered oral medications as main modality for control and only $15.8 \%$ of these patients attributed blood glucose control solely to use of camel milk. Camel milk users were found to use more of home remedies $(13.7 \%, n=13)$, homeopathic medicine $(15.8 \%, n=15)$ and exercise $(45.3 \%, n=43)$ as adjunct modalities to control their blood glucose as compared to $6.5 \%, 8.9 \%$ and $31.4 \%$ of non-users. $71.6 \%(n=121)$ of non- users used dietary modification to manage diabetes as compared to $47.4 \%(n=45)$ users. $71 \%(n=121)$ non-users were regularly measuring their blood glucose levels as compared to $56.8 \%(n=54)$ users of camel milk. Conclusions: Diabetics drinking camel milk showed a marked decrease in mean Fasting Blood Sugar values as compared to non-users. More experimental studies should be conducted on a larger scale and on different regions so as to ascertain the biological plausibility.

Key words: Diabetic patients, Camal Milk, Fasting blood (FBG)

Article Citation: Saeed Z, Hasan Z, Sohail FA. Type II diabetic patients; use of camel milk in Karachi: a cross sectional survey. Professional Med J 2015;22(9):1159-1163. DOI: $10.17957 / T P M J / 15.2938$

\section{INTRODUCTION}

Diabetes is an endocrine disorder in which there is a lack of production of or effect of insulin, a hormone produced the pancreas, responsible for normal glucose metabolism in the body. This inability to produce or use insulin has multifactorial causation from genetic predisposition to environmental and non-specific factors. Two most common presentations of diabetes mellitus are type I and type II. Type I is due total lack of insulin production at an early age and is therefore also called insulin dependent diabetes. Type II has its onset at a later age with mostly either a low level of insulin production or decreased cellular sensitivity to a normal or increased insulin production. In the absence of normal insulin mediated glucose metabolism, serum blood glucose remains high, a condition called hyperglycemia. Hyperglycemia over long periods, damages the vascular endothelial cells in many organs leading to chronic, long term and often-irreversible damage to retina, renal glomeruli, nerve sheaths and 
other tissues. $^{1}$

According to WHO estimates, diabetes type II is globally a major cause of morbidity and mortality and projected to become the seventh leading cause of death by $2030 .{ }^{2}$ In a systematic analysis of national, regional and global trends in diabetes prevalence over 30 years, it was found that the number of people with diabetes increased from 153 (127-182) million in 1980, to 347 (314-382) million in $2008 .{ }^{3}$ With a global prevalence of $6.4 \%$, a major portion of this burden lives in the developing countries of the world. ${ }^{4}$ Published studies provide evidence that prevalence of diabetes is rapidly increasing worldwide and significant number of people suffering from its immediate and long-term complications due to inadequate management..$^{{ }^{\prime} 6^{\prime} 7^{\prime} 8^{\prime} 9^{\prime} 10}$ In Pakistan, estimated $11.1 \%$ people are diabetic with many more under the clinical horizon of its epidemiological iceberg. ${ }^{11} \mathrm{In}$ the absence of any cure, management is based on modification of risk factors and use of a variety of oral medications and exogenous insulin to keep the blood glucose level in control. Maintaining a normal range of fasting blood glucose (FBG) level since onset of condition also prevents or delays the associated complications. Risk factor modification includes lifestyle changes in diet and physical activity to maintain a healthy weight and balanced food consumption. Adherence to medication, dietary regimens and regular exercise are required for life and this is often a difficult goal for diabetics. For this reason, patients often seek adjunct therapies and remedies to help maintain normal glucose levels. Health systems should investigate effective local alternates to manage diabetes in communities.

Camel milk is a staple source of dairy inparts of the world with predominant desert topography, where camels are reared for travel and transport. In certain communities that consume camel milk, the incidence of diabetes is negligible. ${ }^{12}$ This is attributed to the fact that camel milk contains 52 units of insulin in each liter ${ }^{13},{ }^{14}$ Additionally it also has a beneficial mix of lactose and protein content that has anticancer, hypo allergic, lipid lowering and glucose lowering properties. ${ }^{15}$ Experimental research has found that certain components of camel milk have insulin like actions and therefore, replace its deficiency, insufficiency or ineffectiveness in the animal body. ${ }^{16^{\prime} 17^{\prime} 18}$

In 2008 and 2010, floods inundated many areas of rural Sindh while many communities in predominantly desert areas suffered from drought. This resulted influx of rural communities into peripheries of urban areas like Karachi. Camel rearing communities found their livelihood by using camels for entertainment rides and selling its milk. Many fresh milk outlets started an aggressive marketing of camel milk advertising its health benefits with especial emphasis on glucose lowering/ diabetes control properties. Anecdotal evidence showed a high propensity of diabetes type II patients queuing to purchase camel milk at these outlets. Therefore this research was conducted to determine its frequency of use by type II diabetic patients in urban setting of Karachi and also to describe the characteristics of patients who use camel milk. Additionally, it will also provide evidence for future studies in local population to determine the use of camel milk as an alternate in management of diabetes.

\section{METHODS}

A cross sectional questionnaire based survey was conducted between May to August 2013. Minimum sample size using $11.1 \%$ prevalence of type II diabetes mellitus, confidence interval of 95\% and 5\% margin of error and finite population correctionfor large population was calculated to be 152. Permission to collect data from outpatients twice a week, was obtained from two private (Liaquat National Hospital \& Jinnah Medical College Hospital) and one public sector hospital (Jinnah Postgraduate Medical Centre) in Karachi. Every second type II diabetes patient, known to be taking oral hypoglycemic medication or insulin to control serum blood glucose, registering at outpatient departments for diabetes management on data collection days was requested to participate. After obtaining informed consent, a structured pre-coded questionnaire was filled by trained interviewer. Questions focused on how patients were managing their diabetes includ- 
ing use of oral hypoglycemic/insulin and any adjunct therapies such as homeopathic, herbal, home remedies and camel milk. Two laboratory assessed fasting blood (FBG) readings from previous three months were also recorded from their files. Those who affirmed the use of camel milk were asked further questions on reasons for use and consumption pattern. All responses were entered into SPSS version 21.0 and descriptive frequencies and statistics were obtained for camel milk users and non-users.

\section{RESULTS}

300 patients consented to participate and filled the questionnaire. 36 forms did not have two FBG lab reports from previous three months and were excluded. In the remaining sample size of $\mathrm{n}=264$, camel milk use frequency was $35.98 \%$ $(n=95)$. In the preceding three months, the median FBG of users was $121.0 \mathrm{mg} / \mathrm{dl}$ as compared to median FBS of non-users $(64.01 \% ; n=169)$ of $202.06 \mathrm{mg} / \mathrm{dl}$.The comparison of FBS readings is shown in Graph 1. $90.5 \%(n=86)$ of all users considered oral medications as main modality for control and only $15.8 \%$ of these patients attributed blood glucose control solely to use of camel milk. Camel milk users were found to use more of home remedies $(13.7 \%, n=13)$, homeopathic medicine $(15.8 \%, n=15)$ and exercise $(45.3 \%$, $\mathrm{n}=43$ ) as adjunct modalities to control their blood glucose as compared to $6.5 \%, 8.9 \%$ and $31.4 \%$ of non-users. However $71.6 \%(n=121)$ of nonusers used dietary modification to manage diabetes as compared to $47.4 \%(n=45)$ users. $71 \%$ $(\mathrm{n}=121)$ non-users were regularly measuring their blood glucose levels as compared to $56.8 \%$ $(n=54)$ users of camel milk. Table I shows the pattern of camel milk consumption.

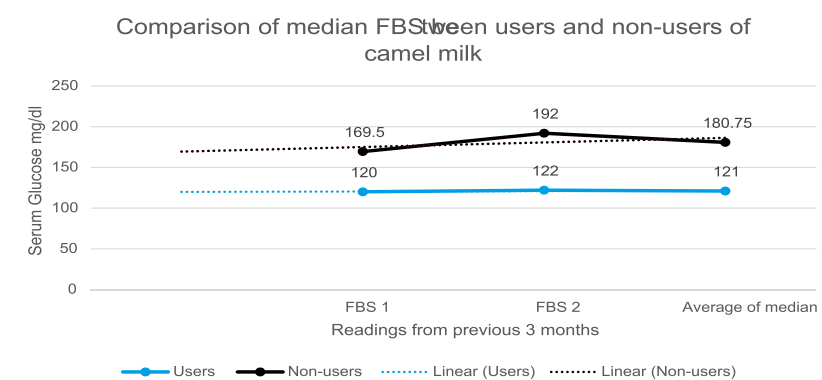

Graph-1. Comparison of FBS between users and nonusers of camel milk

\begin{tabular}{|c|c|c|}
\hline Question & $\begin{array}{l}\text { Most frequent } \\
\text { response }\end{array}$ & Valid \% (n/95) \\
\hline Reason for use & $\begin{array}{l}\text { General health } \\
\text { and vitality }\end{array}$ & $51.6 \%(n=49)$ \\
\hline \multirow{2}{*}{ Recommended by } & Family/friends & $50.5 \%(n=48)$ \\
\hline & Doctor & $5.3 \%(n=5)$ \\
\hline \multirow{3}{*}{ Using since } & $<6$ months & $37.89 \%(n=36)$ \\
\hline & $6-1$ year & $26.3 \%(n=25)$ \\
\hline & $1-2$ years & $25.3 \%(n=24)$ \\
\hline \multirow{2}{*}{$\begin{array}{l}\text { Amount } \\
\text { consumed }\end{array}$} & $1 / 2$ glass/use & $55.8 \%(n=53)$ \\
\hline & 1 glass/use & $42.1 \%(n=40)$ \\
\hline \multirow{3}{*}{ Frequency of use } & $\begin{array}{l}\text { Once on } \\
\text { alternate days }\end{array}$ & $24.2 \%(n=23)$ \\
\hline & $\begin{array}{l}\text { Once every } \\
\text { week }\end{array}$ & $30.5 \%(n=29)$ \\
\hline & Once a month & $26.3 \%(n=25)$ \\
\hline
\end{tabular}

\section{DISCUSSION}

Our study findings show that about one third of type II diabetes patients in Karachi are using camel milk. However, most are doing so for its general health benefits and not with specific intent to control blood glucose level. Users also have a much better blood glucose control as demonstrated by better FBGs as compared to non-users of camel milk. This is consistent with a number of comparative human studies, which have all found a significantly lower blood glucose levels among camel milk users. ${ }^{1}$ In our study, users in our study, attribute this control to diabetic medications, are using other remedies, and exercise more than the non-users of camel milk. This shows that patients opting to drink camel milk, maybe generally more health conscious, compliant to medication and committed to controlling their blood glucose level by various means, suggested mostly by social contacts.

Although literature has proven the insulin like action of camel milk components, the amount of milk, its frequency and duration of use to control or prevent diabetes type II, is still unknown and require prospective experimental studies with thorough control of confounders. The highest quantity used by our research participants is one glass on alternate days since two years and least 
is half glass every month since $<6$ months. This demonstrates that although camel milk is being used by type II diabetics in urban setting of Karachi, it does not form a significant part of daily diet in frequency or quantity. In experimental studies, quantities up to $500 \mathrm{ml}$ per day was used on a regular basis for a number of weeks. ${ }^{2}$ The lack of scientific evidence involving local or large populations and the consequent non-recommendation by health professionals may be the reason for this. Additionally, despite being available at convenient and central locations, camel milk is also more expensive.

\section{CONCLUSION}

Diabetics drinking camel milk showed a marked decrease in mean Fasting Blood Sugar values as compared to non-users. More experimental studies should be conducted on a larger scale and on different regions so as to ascertain the biological plausibility.

Copyright(C) 06 July, 2015.

\section{REFERENCES}

1. K. Park. Park Textbook of Preventive \& Social Medicine. $22^{\text {nd }}$ Edition. India.Banarsidas Bhanot.2013.

2. World Health Organization. Media centre; Diabetes. URL: http://www.who.int/mediacentre/factsheets/fs312/ en/DOA May 2015.

3. Danaei G, Finucane MM, Lu Y, et al. National, regional, and global trends in fasting plasma glucose and diabetes prevalence since 1980: systematic analysis of health examination surveys and epidemiological studies with $\mathbf{3 7 0}$ country-years and $\mathbf{2 . 7}$ million participants. Lancet. 2011; 378 (9785); 31-40 URL: www. ncbi.nlm.nih.gov/pubmed/21705069DOA May 15.

4. Gakidou E, MallingerL, Abbott-Klafter J, et al. Management of diabetes and associated cardiovascular risk factors in seven countries: a comparison of data from national health examination surveys.Bulletin of the World Health Organization 2011; 89:172-18 doi: 10.2471/BLT.10.080820 URL: www.who.int/bulletin/volumes/89/3/10-080820/en/DOA May 2015).

5. Aekplakorn W, Abbott-Klafter J, Premgamone A, et al. Prevalence and management of diabetes and associated risk factors by regions of Thailand: Third National Health Examination Survey 2004. Diabetes Care 2007; 30: 2007-12 doi:10.2337/dc06-2319 DOA May 2015.
6. Cowie CC, Rust KF, Byrd-Holt DD, Eberhardt MS, Flegal $\mathrm{KM}$, Engelgau MM, et al., et al. Prevalence of diabetes and impaired fasting glucose in adults in the U.S. population: National Health And Nutrition Examination Survey 1999-2002. Diabetes Care 2006; 29: 12638URL: $\quad$ www.ncbi.nlm.nih.gov/pubmed/16732006DOA April 2015.

7. Gu D, Reynolds K, Duan X, Xin X, Chen J, Wu X, et al., InterASIA Collaborative Group, et al. Prevalence of diabetes and impaired fasting glucose in the Chinese adult population: International Collaborative Study of Cardiovascular Disease in Asia (InterASIA). Diabetologia 2003; (46): 1190-8 URL: www.ncbi.nlm.nih. gov/pubmed?cmd=Link\&dbFrom $=$ PubMedDOA April 2015.

8. Kim SM, Lee JS, Lee J, Na JK, Han JH, Yoon DK, et al., et al. Prevalence of diabetes and impaired fasting glucose in Korea: Korean National Health and Nutrition Survey 2001. Diabetes Care 2006; (29): 226-31 URL:http://www.ncbi.nlm.nih.gov/pubmed/1644 3864 DOA April 2015.

9. Mainous AG, Diaz VA, Saxena S, Baker R, Everett CJ, Koopman RJ, et al., et al. Diabetes management in the USA and England: comparative analysis of national surveys. J R Soc Med 2006; (99): 463-9 URL:http:// www.ncbi.nlm.nih.gov/pubmed/16946390 DOA April 2015.

10. Rull JA, Aguilar-Salinas CA, Rojas R, Rios-Torres JM, et al. Epidemiology of type 2 diabetes in Mexico. Arch Med Res 2005; (36): 188-96 URL:http://www.ncbi.nlm. nih.gov/pubmed/15925009 Date of access April 2015.

11. Hakeem R, Fawwad A. Diabetes in Pakistan: Epidemiology, determinants and prevention. $J$ of Diabetology 2010;3:4.

12. Agrawal RP, Budania S, Sharma P,et al. Zero prevalence of diabetes in camel milk consuming Raica community of north-west Rajasthan, India. Diabetic Research andClinical Practice 2007; 76(2):290-6. URL: http://www.ncbi.nlm.nih.gov/pubmed/22783713 DOA April 2015.

13. Gizachew A, Teha J, Birhanu T. Review on Medicinal and Nutritional Values of Camel Milk. Nature and Science 2014; 12(12) URL:http://www.sciencepub.net/nature/ns1212/006_27358ns121214_35_40.pdf DOA April 2015.

14. R. Mullaicharam. A review on medicinal properties of Camel milk. World Journal of Pharmaceutical Sciences. Sci2014; 2(3): 237-242. URL: http://www.wjpsonline. org/admin/uploads/tCQEW6.pdf DOA April 2015.

15. G. Konuspayeva, B. Faye, G. Loiseau. The composi- 
tion of camel milk: A meta-analysis of the literature data-StudyReview.Journal of Food Composition and Analysis 22 (2009); 95-101. URL:http://www.researchgate.net/publication/222397882_The_composition_of camel_milk_A_meta analysis_of the literature_data/ file/50463 517ā58006e260.pdf DOA May 2015.

16. Al-Numair KS, Govindasamy C, Alsaif MA. Influence of camelmilkonglycoproteincomponentsin streptozotocin-diabeticrats.Journal of CamelPracticeand Research 2011, Volume: 18 (1); 15-20 URL:http://www.indian journals.com/ijor.aspx?target $=$ ijor:jcpr \&volume $=18 \&$ is sue $=1$ \&article $=03$ DOA April 2015.

17. Isa SA, Ibrahim KG, Abubakar I. Effect of Camel Milk's Supplementation on Serum Glucose Levels, Lipid Profile and Body Weight of Alloxan-Induced Diabetic Rats.Nigerian Journal of Basic and Applied Sciences. 2013; 21 (3); 187-192 URL: http://www.scopemed. org/?mno=48089DOA April 2015.
18. Korish AA. The antidiabetic action of camel milk in experimental type 2 diabetes mellitus: an overview on the changes in incretin hormones, insulin resistance, and inflammatory cytokines. Hormone and Metabolic Research. 2014, 46(6):404-411. URL: http:// www.ncbi.nlm.nih.gov/pubmed/24627103 DOA April 2015.

19. Agrawal RP, Sharma P, Gafoorunissa SJ et al. Effect of camel milk on glucose metabolism in adults with normal glucose tolerance and type 2 diabetes in Raica community: a crossover study. Acta bio-medica2011;82(3):181-6. URL:http://www.ncbi.nlm.nih.gov/ pubmed/22783713DOA April 2015.

20. Ejtahed HS, Naslaji AN, Mirmiran P, et al. Effect of Camel Milk on Blood Sugar and Lipid Profile of Patients with Type 2 Diabetes: A Pilot Clinical Trial.International Journal of Endocrinology and Metabolism. 2015; 13(1): e21160. Published online 2015 Jan 22. doi: 10.5812/ ijem.21160DOA May 2015.

\section{PREVIOUS RELATED STUDY}

Mohammad Mohsin Rana, Muhammad Saeed Akhtar, Badar Bashir, Abaid-ur-Rehman. TYPE 2 DIABETICS; THE RELATIONSHIP BETWEEN THE SERUM CHOLESTEROL AND TRIGLYCEROIDS (Original) Prof Med Jour 14(2) 337-343 Apr, May, Jun, 2007.

Usman Khurshid, Ibrahim Us. SIALIC ACID AS A PREDICTOR OF TYPE 2 DIABETES MELLITUS (Original) Prof Med Jour 15(2) 273-280 Apr, May, Jun 2008.

Amena Rahim, Amir Shahzad. PIOGLITAZONE VS DLIMEPIRIDE; TO EVALUATE THE EFFECT OF ON RENAL FUNCTION TESTS IN TYPE 2 DIABETES IN PATIENTS (Original) Prof Med Jour 18(3) 450-453 Jul, Aug, Sep 2011.

Syed Shahjee Husain, Muhammad Rizwan Javed, Sara Ahmad Ali. DIABETIC KETOACIDOSIS; THE PRECIPITATING ENTITIES IN PATIENTS WITH TYPE 2 DIABETES MELLITUS (Original) Prof Med Jour 18(1) 82-82 Jan, Feb, Mar 2011.

Raheel Iftikhar, Muhammad Adnan Manzar, Fatima Saeed. Type 2 diabetes mellitus; determination of frequency and pattern of hypertension in patients (Original) Professional Med J Mar-Apr 2012;19(2): 259-263.

\section{AUTHORSHIP AND CONTRIBUTION DECLARATION}

\begin{tabular}{|c|c|c|c|}
\hline Sr. \# & Author-s Full Name & Contribution to the paper & Author $=\mathbf{s}$ Signature \\
\hline 1 & Dr. Zeba Saeed & $\begin{array}{l}\text { Principal investigator, } \\
\text { conception, design, data } \\
\text { collection, authorship }\end{array}$ & \\
\hline 2 & Dr. Zainab Hasan & $\begin{array}{l}\text { Data analysis \& results, final } \\
\text { manuscript preparation, } \\
\text { intellectual review }\end{array}$ & \\
\hline 3 & Dr. Fadieleh Adnan Sohail & $\begin{array}{l}\text { Literature Review \& } \\
\text { Discussion }\end{array}$ & \\
\hline
\end{tabular}

